Acta vet. scand. $1968,9,151-167$.

From the Department of Clinical Biochemistry, Royal Veterinary

College, and the Department of Pathology, National Veterinary

Institute, Stockholm, Sweden.

\title{
CHEMICAL AND MORPHOLOGICAL STUDIES OF THYROID FUNCTION IN LACTATING CATTLE
}

\author{
By \\ J.-A. Nyberg, P. O. Nilsson, B. Crabo and L. Ekman
}

In human medicine, atoxic goitre is used as a collective term for a number of thyroid conditions of varying aetiology, clinical features and pathological anatomy. It denotes every form of enlargement of the thyroid gland without signs of hyperfunction. In view of the occurrence of the disease, the terms endemic goitre and sporadic atoxic goitre are often applied. Hitherto known causes of endemic goitre are iodine deficiency and goitrogens present in nature. In addition, genetic factors may play a role, especially in regions where endemic goitre has existed for generations (Roche \& Lissitzky 1960). Separately or in combination, these factors produce a deficiency of thyroid hormone in the organism. Stimulation of the thyroid by thyrotropic hormone (TSH) is elicited via the pituitary, with the resulting appearance of goitre.

In the 1920 'es and 1930 'es, the incidence of goitre in man in Sweden was elucidated by means of clinical studies (Höjer 1931). Hojer found that, in certain regions, goitre was present in about $25 \%$ of the population. Such regions were Dalecarlia, South-East Norrland and certain parts of Småland. As a result of Höjer's findings, the National Board of Health started to recommend iodization of kitchen salt. The indicence of goitre in man nevertheless remained high in some parts of Sweden. Thus, Johnsson (1965) reported that about $30 \%$ of 1000 consecutive patients at the Sundsvall hospital exhibited atoxic goitre. In Western Sweden, an extremely high incidence of familial goitre has been demonstrated in man (Heimann 1965). As a practical consequence 
of the persisting high incidence, the National Board of Health stipulated that all kitchen salt marketed in Sweden should contain $50 \mathrm{mg}$ of sodium or potassium iodide per $\mathrm{kg}$ (Kungl. Medicinalstyrelsen 1966).

Höjer also reported a high incidence of goitre in domestic animals in regions with a high incidence in man. A study of the occurrence of congenital goitre in calves in some counties in Central Sweden disclosed numerous cases in the counties of Södermanland, Örebro, Västmanland and Kopparberg, whereas few cases were noted in the counties of Uppsala and Stockholm (Obel et al. 1950). Goitre is known to appear chiefly in newborn calves and lambs (e.g. Hoflund 1963). This form of goitre can, as a rule, be prevented by prophylactic iodine treatment of the cows during the last 5 months of pregnancy and of the ewes during the last 3 months. However, since the mineral fodder mixtures used nowadays contain iodine, it is generally unnecessary to administer any additional iodine. The reason why calves with congenital goitre are still occasionally found in certain regions may be that the dams have been given too little, or none, of these mineral fodder mixtures. Another reason may be the presence of so-called goitrogens in the cows' fodder. Goitrogens are known to be present in certain plants, e.g. kale and rape (e.g. Hoflund). This implies that thyroid disturbances may occur despite an adequate supply of iodine, when the animals are fed excessive amounts of such plant products.

Hypofunction of the thyroid in lactating cattle has been diagnosed clinico-chemically in Sweden (Ekman \& Gustafsson 1965). Clinically, the only manifestation of hypofunction was a disturbance in fertility, i.e., in the form of so-called repeat breeding. No palpable enlargement of the thyroid was demonstrable.

No systematic study of the incidence of thyroid disturbances in adult cattle has been made in Sweden, analogous to those in man (e.g. Johnsson). Such an investigation would, naturally, be of interest from the point of view of comparative medicine. Moreover, the functional state of the thyroid may indirectly be of importance with respect to food hygiene. Thus, it has clearly been demonstrated that, in an acute fall-out situation, milk is the chief foodstuff through which radioactive iodine is transmitted to man (e.g. Bustad et al. 1964). The concentration of radioactive iodine in milk can be envisaged to vary with the functional state of the thyroid (Bruner 1964). 
An account is given in this paper of the preliminary results of a study of which one of the aims was to ascertain the incidence of thyroid disturbances in adult lactating cattle in certain regions of Sweden. Histo-pathological studies were combined with clinicochemical analyses. We considered that this would permit an idea to be obtained of the extent to which histologically demonstrable thyroid changes are reflected in some chemical blood analyses of the state of thyroid function commonly used in human medicine.

\section{MATERIAL AND METHODS}

The investigation was made on 255 adult cows from 5 different slaughterhouses in Sweden. The collection of specimens took place from October 1966 to March 1967. The localization and reception area of the slaughterhouses, the time of sampling, the cows' age and the distribution by breed are given in Table 1 .

On the morning of the day on which the animals were slaughtered, blood specimens were taken by puncture of the jugular vein. An ocular inspection was made concurrently. A rectal examination was also made, to establish the presence of

T a b le 1. Localization of slaughterhouses, reception area, time of year for sampling, range of age in cattle, mean age and number of cattle of different breeds.

\begin{tabular}{|c|c|c|c|c|c|c|c|c|}
\hline \multirow{2}{*}{$\begin{array}{l}\text { Slaughter- } \\
\text { house } \\
\text { located } \\
\text { in }\end{array}$} & \multirow{2}{*}{$\begin{array}{l}\text { Reception } \\
\text { area } \\
\text { (County) }\end{array}$} & \multirow{2}{*}{$\begin{array}{c}\text { Time } \\
\text { of } \\
\text { sampling }\end{array}$} & \multirow{2}{*}{$\begin{array}{c}\text { Age } \\
\text { (years) } \\
\text { Mean } \\
\text { age }\end{array}$} & \multicolumn{5}{|c|}{ Number of cows of different breeds ${ }^{1}$ ) } \\
\hline & & & & SRB & SKB & SLB & $\begin{array}{l}\text { cross- } \\
\text { breed }\end{array}$ & total \\
\hline Uppsala & $\begin{array}{l}\text { Uppsala and } \\
\text { Stockholm }\end{array}$ & $\begin{array}{l}\text { October } 1966 \\
\text { March } 1967\end{array}$ & $\begin{array}{c}3-16 \\
6.5\end{array}$ & 60 & & & 1 & 61 \\
\hline östersund & Jämtland & $\begin{array}{l}\text { October- } \\
\text { November } 1966\end{array}$ & $\begin{array}{c}3-18 \\
7\end{array}$ & 4 & 42 & 2 & 2 & 50 \\
\hline Sävsjö & Jönköping & November 1966 & $3-15$ & 43 & & & & 43 \\
\hline Halmstad & Halland & December 1966 & $\begin{array}{c}3-18 \\
8\end{array}$ & 28 & & 19 & 1 & 48 \\
\hline \multirow[t]{2}{*}{ Sundsvall } & Västernorrland & January 1967 & $\underset{9}{3-19}$ & 28 & 20 & & 5 & 53 \\
\hline & & & Total & 163 & 62 & 21 & 9 & 255 \\
\hline
\end{tabular}

1) SRB denotes Swedish Red and White Breed.

SLB denotes Swedish Friesian Breed.

SKB denotes Swedish Polled Breed. 
e.g. pregnancy, ovarian cysts and corpora lutea. In addition, a questionnaire was sent to the owners of the cows involved. They were asked to give data on such matters as the cow's age, stage of pregnancy, milk production, feeding, diseases and cause of slaughter. In the study of which an account is given in the following, only apparently clinically healthy cows were included.

The blood analyses of the functional state of the thyroid consisted of determination of protein-bound iodine (PBI) in serum, as well as determination of the uptake by the erythrocytes in vitro of I $^{131}$-labelled L-triiodothyronine (EU). PBI was determined according to Baker et al. (1951), and EU by Thorell's modification (1965) of Wang's method (1963). The EU test was made on heparinized blood $24-48$ hrs. after withdrawal. The blood serum was also separated off $24-48 \mathrm{hrs}$. after sampling, the sera then being stored at $-20^{\circ} \mathrm{C}$ until the PBI determination.

Immediately after slaughter, the thyroid glands were dissected out, examined macroscopically and weighed. Material for histological examination was taken from the centre of each of the thyroid lobes and fixed at once both in $10 \%$ aqueous solution of formaldehyde and in Bouin's fixative.

After paraffin embedding and sectioning, the sections were stained with van Gieson's stain, with haematoxylin and eosin, and with PAS.

In the histological evaluation of the thyroid glands, the following scheme was used, it being based mainly on the criteria of the classification set up by Wahlberg (1933).

A. Normal thyroid gland

B. Interfollicular adenomatosis

(a) Mild

(b) Moderate-marked

(c) Adenomatous solidification

C. Intrafollicular proliferation

(a) Papillary proliferation

(b) Papillomatous proliferation

1) Mild

2) Moderate-marked

(c) Papillomatous solidification

D. Goitre

(a) Colloid

(b) Parenchymatous

(c) Colloid and parenchymatous 


\section{Definitions}

A. A thyroid gland is denoted as normal when its features are dominated by round to oval follicles of equal sizes, with lowcubical epithelium (Fig. 1). The follicles are well filled by homo-
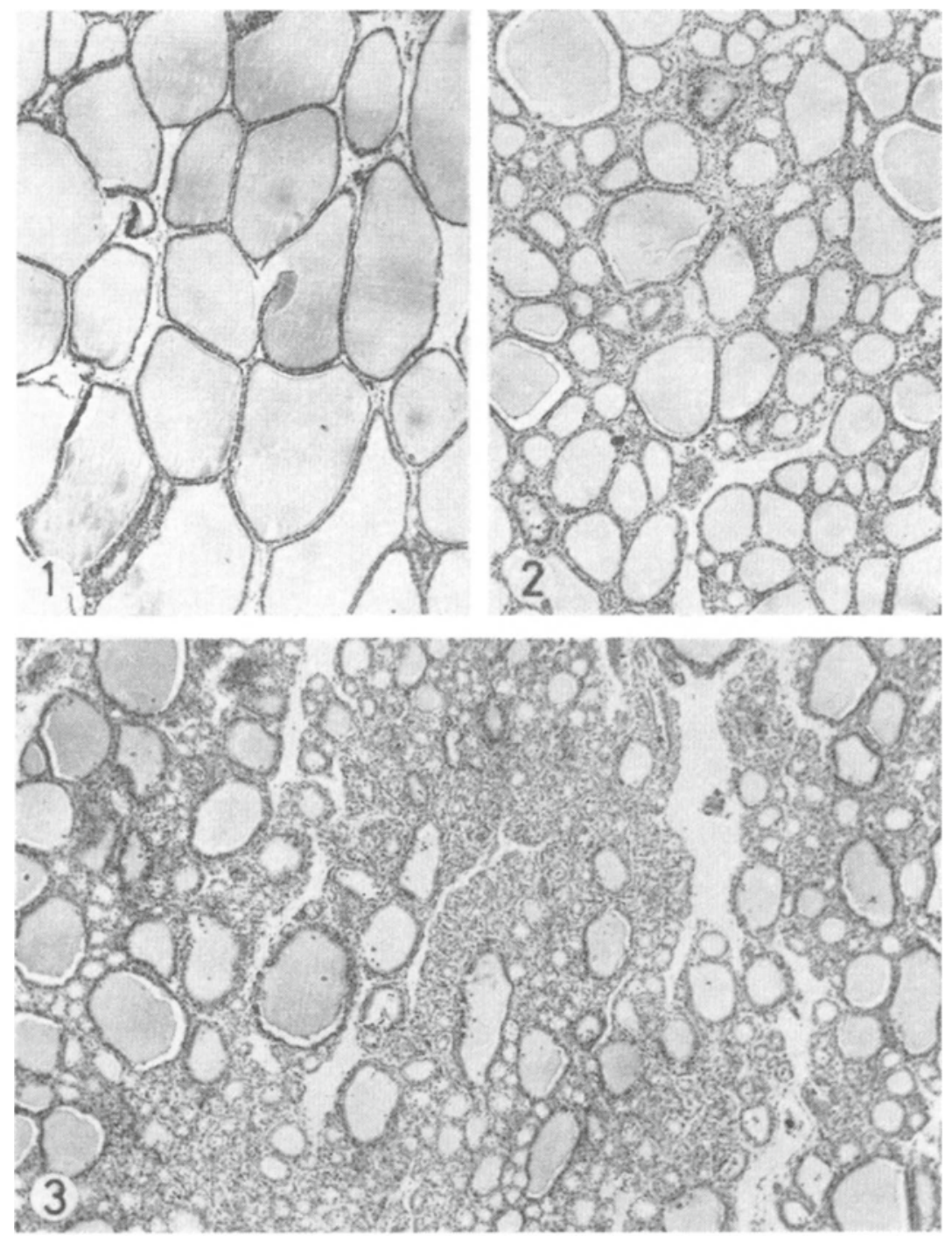

F i g u re 1. Normal thyroid gland $(\mathrm{H} \& \mathrm{E}, \times 50)$.

Figure 2. Moderate interfollicular adenomatosis $(\mathrm{H} \& \mathrm{E}, \times 50)$.

F i g u r e 3. Marked interfollicular adenomatosis $(\mathrm{H} \& \mathrm{E}, \times 50)$. 
geneous colloid, which is weakly eosinophilic. The number of cells in the follicles ranges from $40-100$.

B. By interfollicular adenomatosis is meant an increase in interfollicularly situated epithelial cells, microfollicles (mean number of cells in section 5-14) and small follicles (mean cell number 15-40). Depending on the proportion of normal follicles to micro-small follicles, the change is denoted as mild, moderatemarked or as adenomatous solidification (cf. Figs. 2-4).

C. Intrafollicular proliferation denotes an increase in the number of epithelial cells in the follicles. In the mildest form -papillary proliferation - bulges into the follicular lumen are seen, in the form of cell cushions or stroma-bearing finger-like epithelial projections. The intrafollicular hyperplasia may pass into a stage denoted as papillomatous proliferation (cf. Fig. 5). The cell indentations are then more marked, and segmentation of the original follicles into small vesicles is seen in places. The final stage of intrafollicular hyperplasia is denoted as papillomatous solidification. The follicle lumen is then almost completely filled with cell accumulations. This condition is distinguished from adenomatous solidification by the fact that the perifollicular connective tissue can be observed around the original follicle.

D. Goitre is used to denote those glands which are enlarged, with an associated increase in weight. On the basis of the thyroid weights in cattle breeds included in the present material, glands from cows of the SRB weighing over $54 \mathrm{~g}$ were evaluated as increased in weight, and were therefore classified as goitre. This limit, $54 \mathrm{~g}$, is based on the calculation of the mean weight plus 2 standard deviations (Fig. 7). The corresponding weight limit for SKB cows was $44 \mathrm{~g}$, and for SLB cows $51 \mathrm{~g}$. Depending on the histological features, the goitre was denoted as colloid (Fig. 6), parenchymatous, or colloid and parenchymatous, respectively.

To permit a comparison with the results of the chemical analyses, the thyroid glands were divided into 3 groups from the morphological point of view:

Group I. Normal (A in the classification scheme)

Group II. Slightly changed (Ba, $\mathrm{Ca}$ and $\mathrm{Cb} 1$ in the classification scheme)

Group III. Moderately to greatly changed (Bb, Bc, Cb2, Cc and $\mathrm{D}$ in the classification scheme) 

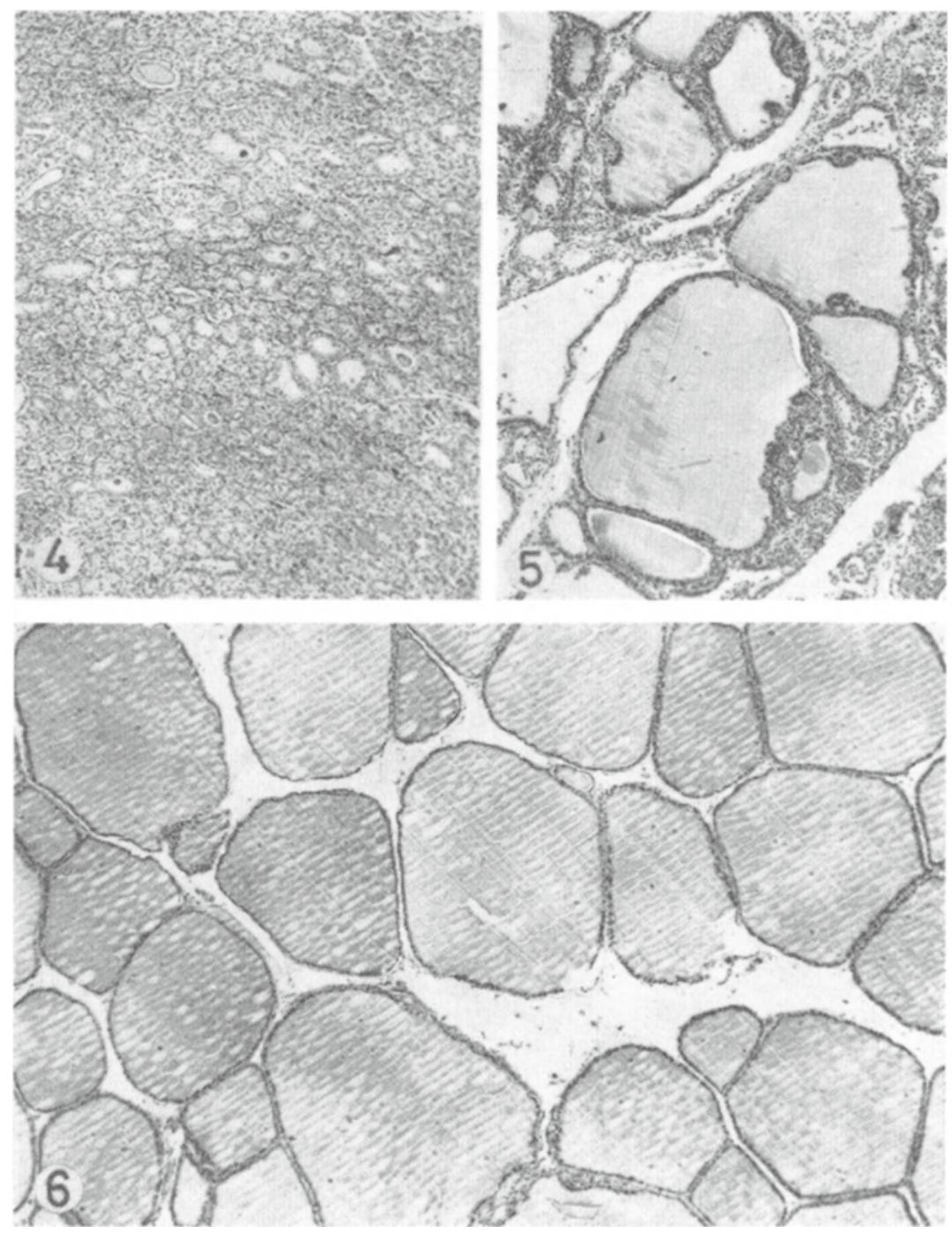

F i g u re 4. Adenomatous solidification $(\mathrm{H} \& \mathrm{E}, \times 50)$.

Figure 5. Mild papillomatous proliferation $(\mathrm{H} \& \mathrm{E}, \times 50)$.

Figure 6. Colloid goitre $(\mathrm{H} \& \mathrm{E}, \times 50)$.

\section{RESULTS}

The absolute and relative incidences of histologically normal and changed thyroid glands, both in the different sampling regions and in the whole material, are given in Table 2 . The most noteworthy finding is that $85 \%$ of the glands from the Sundsvall 
T a b l e 2. Absolute and relative incidence of histologically normal and changed thyroid glands, both in the different sampling regions and in the whole material.

\begin{tabular}{|c|c|c|c|c|c|c|c|c|c|c|c|c|}
\hline \multirow{2}{*}{ Thyroid glands } & \multicolumn{2}{|c|}{ Uppsala } & \multicolumn{2}{|c|}{ Östersund } & \multicolumn{2}{|c|}{ Sävsjö } & \multicolumn{2}{|c|}{ Halmstad } & \multicolumn{2}{|c|}{ Sundsvall } & \multicolumn{2}{|c|}{ Total } \\
\hline & no. & $\%$ & no. & $\%$ & no. & $\%$ & no. & $\%$ & no. & $\%$ & no. & $\%$ \\
\hline Normal & 31 & 50.8 & 16 & 32.0 & 26 & 60.5 & 23 & 47.9 & 8 & 15.1 & 104 & 40.8 \\
\hline Slightly changed & 14 & 23.0 & 20 & 40.0 & 8 & 18.6 & 13 & 27.1 & 7 & 13.2 & 62 & 24.3 \\
\hline $\begin{array}{l}\text { Moderately/ } \\
\text { greatly changed }\end{array}$ & 16 & 26.2 & 14 & 28.0 & 9 & 20.9 & 12 & 25.0 & 38 & 71.7 & 89 & 34.9 \\
\hline & 61 & 100 & 50 & 100 & 43 & 100 & 48 & 100 & 53 & 100 & 255 & 100 \\
\hline
\end{tabular}
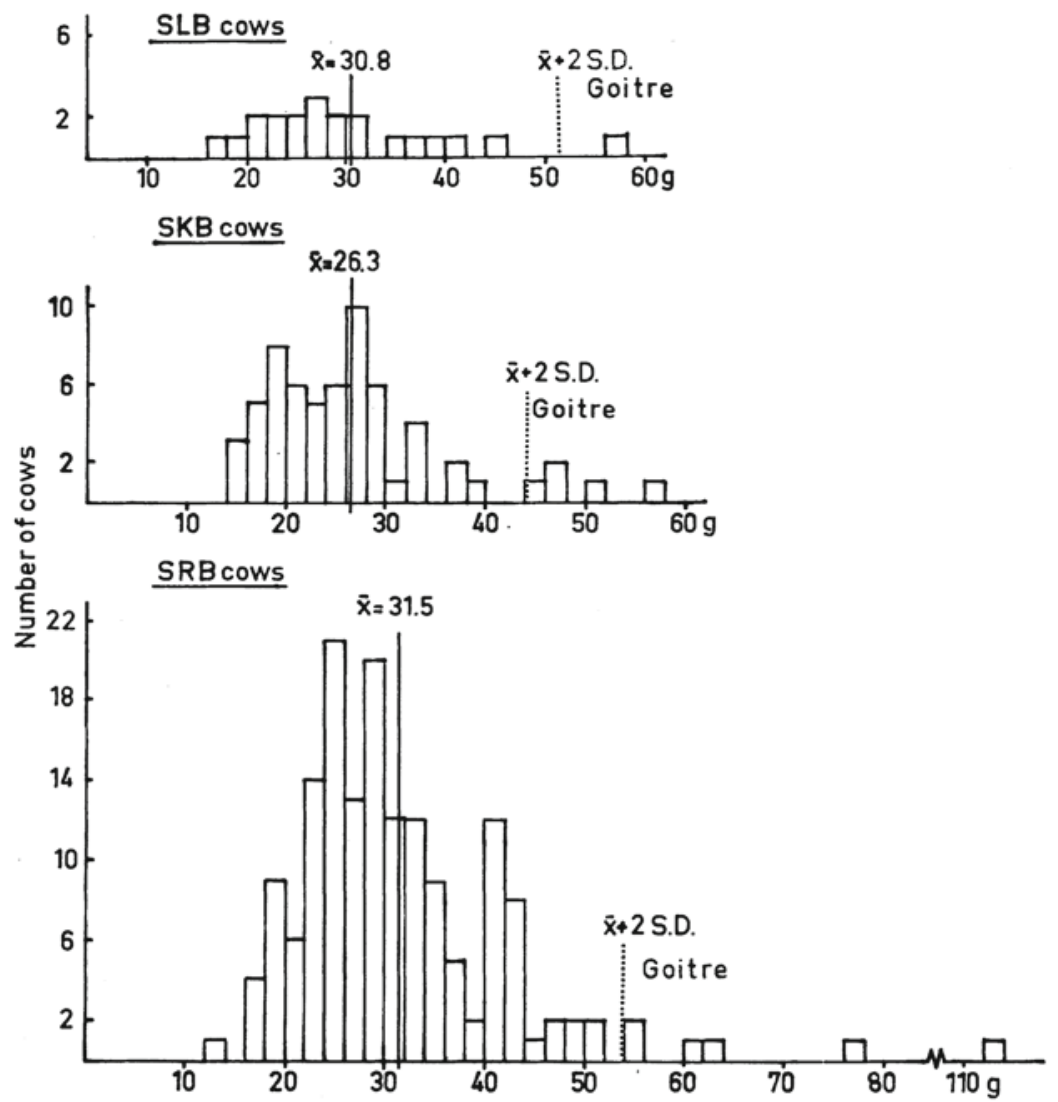

Figure 7. Frequency diagram of absolute thyroid weights in different breeds of cattle in the material. 
region were histologically changed. The corresponding figure for the östersund region was $68 \%$, whereas in the other sampling regions the incidence ranged from 40 to $52 \%$. About $72 \%$ of the glands from the Sundsvall region were regarded as moderately to greatly changed, the corresponding value for the other regions ranging from 21 to $28 \%$.

Fig. 7 is a frequency diagram of the absolute thyroid weights in different breeds of cattle. The mean weight of all glands in the breeds studied was calculated. From the weight point of view, the glands from SRB cows were significantly greater than those from cows of the SKB $\left(t=3.17^{\star \star}\right)$. No significant difference was, on the other hand, present between the thyroid weights of SRB and SLB cows and between the thyroid weights of SKB and SLB cows.

A comparison was made between the weight of the thyroids in SRB cows from the Sundsvall, Uppsala, Sävsjö and Halmstad regions; no significant difference was found. This also applied in a comparison between the thyroid weights in SKB cows from the Ostersund and Sundsvall regions.

It is evident from Fig. 8 that, as far as weight is concerned,

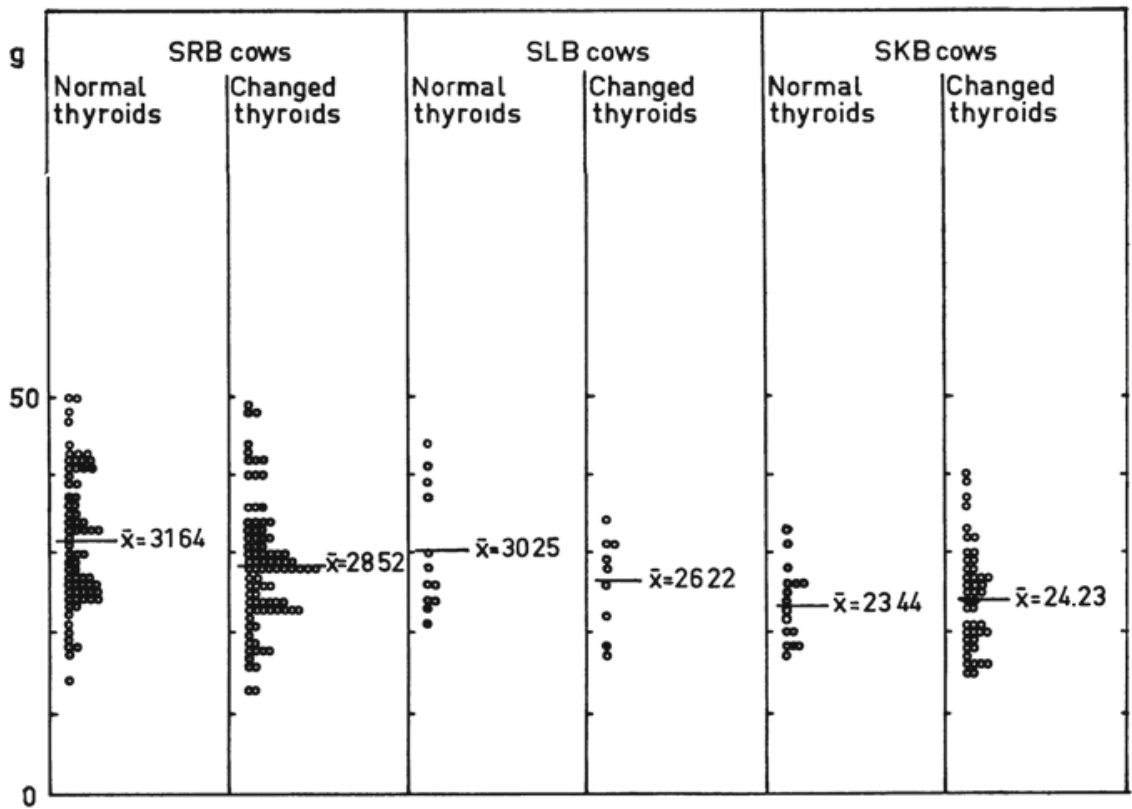

F i g u r e 8. Comparison between absolute thyroid weights of histologically normal and changed thyroid glands in different breeds of cattle. 
no significant difference is present between histologically normal and changed thyroids from cows of the SLB and SKB. In SRB cows, morphologically normal glands proved to weigh significantly more than those with morphological changes $\left(t=2.41^{\star}\right)$. In these calculations, the thyroids classified as goitrous were not included.

Using the present basis of evaluation, totally 12 of the 255 thyroids examined were classified as goitrous. Six of them were from SRB cows, 5 from SKB and 1 from a SLB cow. The largest number of goitrous thyroids (5) derived from the Sundsval region; the corresponding number in the ostersund region was 3 (Table 3). Histologically, 6 of the goitres were classified as colloid, 3 as parenchymatous, and 3 as colloid and parenchymatous.

T a b l e 3. Number of goitrous thyroids and type of goitre in different sampling regions.

\begin{tabular}{|c|c|c|c|c|}
\hline \multirow[b]{2}{*}{ Sampling region } & \multicolumn{3}{|c|}{ Type of goitre } & \multirow{2}{*}{$\begin{array}{l}\text { No. of } \\
\text { goitrous } \\
\text { glands }\end{array}$} \\
\hline & colloid & parenchymatous & $\begin{array}{c}\text { colloid and } \\
\text { parenchymatous }\end{array}$ & \\
\hline Uppsala & 1 & & & 1 \\
\hline östersund & 2 & 1 & & 3 \\
\hline Sävsjö & 2 & & & 2 \\
\hline Halmstad & & & 1 & 1 \\
\hline \multirow[t]{2}{*}{ Sundsvall } & 1 & 2 & 2 & 5 \\
\hline & & & & $\overline{12}$ \\
\hline
\end{tabular}

A statistical comparison was made between the EU values in cows of different breeds from the Sundsvall and Halmstad regions. No significant difference was present. Nor was any significant difference found in a comparison between the $\mathrm{EU}$ values in SRB cows at the Uppsala slaughterhouse in October 1966 and March 1967 (Table 4). It is also evident from the same table that no significant difference is present between the EU in SRB cows from the Uppsala and Sundsvall regions. On the other hand, the EU was significantly higher in cows from these regions than in cows from the Sävsjö and Halmstad regions (Table 4). (The östersund region is not included in this comparison, in view of the small number of cows of the SRB examined). If a corresponding comparison is made between the $\mathrm{EU}$ in all cows in the 
Table 4. Statistical comparison between EU values in cows of Swedish Red and White Breed from different regions.

\begin{tabular}{|c|c|c|c|c|}
\hline & $\begin{array}{l}\text { Uppsala } \\
\text { October }\end{array}$ & Sävsjö & Halmstad & Sundsvall \\
\hline Uppsala & - & $* * *$ & $\star \star \star *$ & 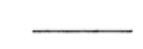 \\
\hline March & & $\mathrm{t}=5.09$ & $\mathrm{t}=4.85$ & \\
\hline Sundsvall & $\longrightarrow$ & $\begin{array}{l}\star * * \\
t=3.33\end{array}$ & $\begin{array}{l}* \star * \\
\mathrm{t}=3.46\end{array}$ & \\
\hline Halmstad & $\begin{array}{l}\star \star \star \star \\
t=6.21\end{array}$ & 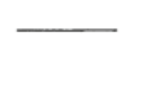 & & \\
\hline Sävsjö & $\begin{array}{l}* \star \star \\
t=6.45\end{array}$ & & & \\
\hline
\end{tabular}

various regions, a similar result is obtained; in addition, the EU in cows from the Ostersund region also showed significantly lower values than those in cows from the Uppsala and Sundsvall regions (Table 5). A significantly lower EU was recorded in cows of the SKB from the Ostersund region than in cows of the same breed from the Sundsvall region $\left(t=5.41^{\star \star \star}\right)$.

T a b le 5. Statistical comparison between EU values in all cows from different sampling regions.

\begin{tabular}{|c|c|c|c|c|c|}
\hline & $\begin{array}{l}\text { Uppsala } \\
\text { October }\end{array}$ & Östersund & Sävsjō & Halmstad & Sundsvall \\
\hline Uppsala & $\longrightarrow$ & $* * *$ & $* * *$ & $* * *$ & \\
\hline March & & $t=4.48$ & $t=5.09$ & $t=5.17$ & \\
\hline Sundsvall & - & $\begin{array}{l}\star \star \star \\
t=4.63\end{array}$ & $\begin{array}{l}* * \\
t=4.92\end{array}$ & $\stackrel{* *}{t=5.40}$ & \\
\hline Halmstad & $\begin{array}{l}* * \\
t=6.45\end{array}$ & $\longrightarrow$ & - & & \\
\hline Sävsjö & $\begin{array}{l}\star \star \star \\
t=6.45\end{array}$ & $\longrightarrow$ & & & \\
\hline östersund & $\begin{array}{l}\star \star \star \\
t=5.41\end{array}$ & & & & \\
\hline
\end{tabular}

A corresponding comparison was made between the PBI values. No significant differences were found, except in a comparison between the values in SRB cows from the Halmstad and Sävsjö regions. The values were almost significantly higher in the former cows $\left(t=2.41^{\star}\right)$. 
It can be inferred from the aforegoing that no significant difference was present between the $\mathrm{EU}$ values in cows of various breeds in the same region. The EU values were therefore compared in cows with morphologically normal, slightly changed, and moderately to greatly changed thyroids (Fig. 9). No signi-

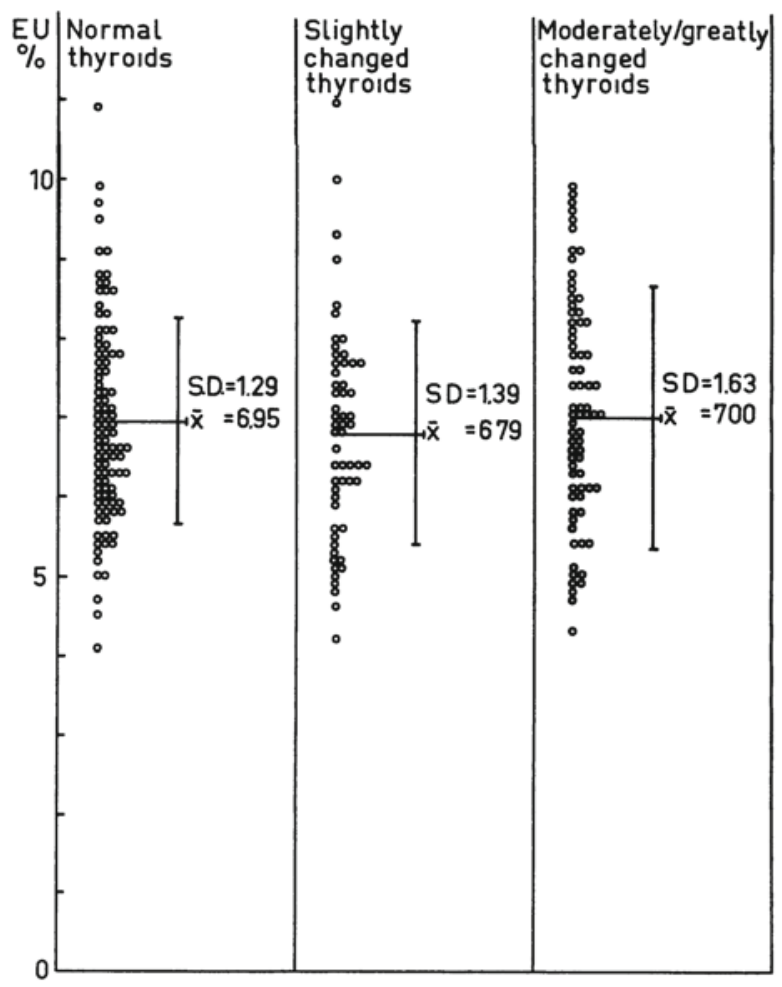

Figure 9. Comparison between EU values in cows with histologically normal, slightly, and moderately to greatly changed thyroid glands.

ficant difference was present between the various groups in this respect. The PBI values recorded are compared in the same way in Fig. 10. Cows with morphologically slightly and moderately to greatly changed thyroids, respectively, showed higher mean values for PBI than cows with normal glands, the difference being highly significant $\left(t=4.03^{\star \star \star}\right)$. No difference was, on the contrary, present between the PBI values in cows with slightly and moderately to greatly changed thyroids. In view of the small size of the material, no more detailed classification can be made with respect to the histological appearance of the thyroid glands. 


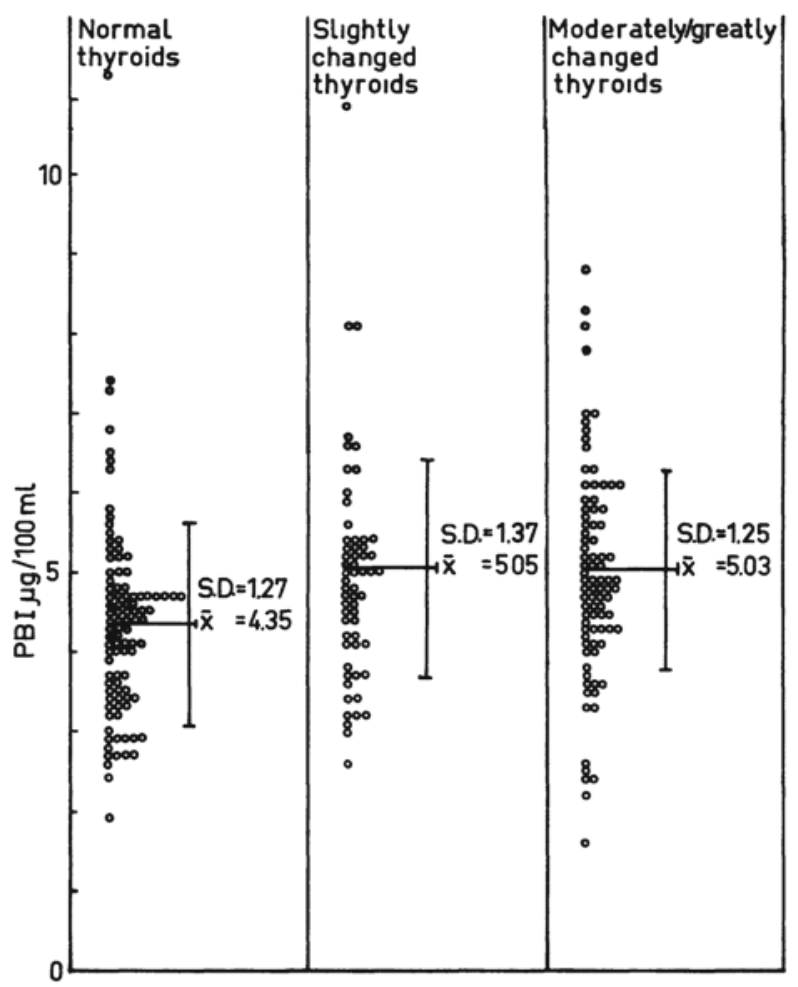

F igure 10 . Comparison between PBI values in cows with histologically normal, slightly, and moderately to greatly changed thyroid glands.

\section{DISCUSSION}

The present study indicates a high incidence of histological changes in the thyroid glands of lactating cattle in all the sampling regions. The incidence is particularly high in the Ostersund and Sundsvall regions, which is in good agreement with the current conditions in man (cf. Johnsson 1965). It is nevertheless remarkable that these histological changes were only exceptionally manifested as marked enlargement of the thyroid. It is evident from a comparison between the absolute weight of the thyroid in morphologically normal and changed glands that when the few goitrous glands have been excluded - the mean weight was, in fact, significantly lower in the latter than in the former in cows of the SRB. Only in 1 case (thyroid weight $112 \mathrm{~g}$ ) was enlargement of the thyroid demonstrable on palpation. In man, a decreased output of thyroid hormones is compensated 
for by hypertrophy of the gland (e.g. Roche \& Lissitzky 1960). Judging by the present results, there is reason to presume that a corresponding compensation in adult cattle takes place by hyperplasia of the glandular parenchyma, without a concurrent increase in weight or volume. It is, however, known that goitre of a corresponding type to that in man occurs in calves (Obel et al. 1950).

Goitre was demonstrable in altogether 12 cows in the present study. Clinico-chemically, all but 2 of them were euthyroid. This is in accordance with the condition in man, since persons with atoxic goitre are usually euthyroid. In man, this state can easily pass into hypothyroidism if the organism is exposed to stress, e.g. in the form of pregnancy (e.g. Clements 1960). We have made no attempt, at the present stage of this investigation, to ascertain the possible existence of hypo- or hyperthyroidism in individual cattle. This would require a detailed analysis of anamnestic, clinical and chemical data. It is nevertheless apparent, in a comparison between the $\mathrm{EU}$ in cows of the same breed from different regions, as well as in a comparison between the EU in all cows in the various regions, that variations in the functional state of the thyroid exist. Thus, cows from the Sävsjö, Ostersund and Halmstad regions had significantly lower EU values than cows from the Uppsala and Sundsvall regions. It is noteworthy that no corresponding difference is present between the various regions with respect to PBI. This is possibly to be ascribed to determination of EU and PBI being 2 essentially different, indirect ways of expressing the functional state of the thyroid from the chemical point of view.

An interesting observation is that, in cows with morphologically changed thyroid glands, the PBI values were higher than in cows with morphologically normal glands, this difference being highly significant $\left(t=4.03^{\star \star \star}\right)$. This can be interpreted to imply that the compensatory structural alterations in the gland result in an increased production of thyroid hormones.

Thus, to sum up, it can be stated that a poor correlation generally exists between the nature of the histological changes and the results of the chemical analyses; this applies especially to EU. A detailed analysis of the individual cows in the material with respect to such factors as milk production, stage of lactation, pregnancy and disturbances in fertility is, however, motivated. It 
might be possible, in this way, to find an agreement between clinical signs of thyroid dysfunction and results of chemical analyses.

\section{REFERENCES}

Baker, S. B., M. J. Humphrey \& M. H. Soley: The clinical determination of protein-bound iodine. J. clin. Invest. 1951, 30, 55-62.

Bruner, H. D.: In, Biology of Radioiodine. ed. L. K. Bustad. Pergamon Press, Oxford 1964, 3-9.

Bustad, L. K., D. H. Wood, E. E. Elefson, H. A. Ragan \& R. O. McClellan: In, Biology of Radioiodine. ed. L. K. Bustad. Pergamon Press, Oxford 1964, 151-154.

Clements, $F$. W.: Health significance of endemic goitre and related conditions. In, Endemic Goitre. WHO Monograph series no. 44, Genève 1960, 235-260.

Ekman, L. \& B. Gustafsson: Hypofunktion av thyroidea och nedsatt fertilitet hos kor. Svensk Vet.-Tidn. 1965, 17, 458-460.

Heimann, P.: Atoxisk struma. Farmacoterapi 1965, 11, 57-87.

Hoflund, S.: Om strumafrekvensen hos nötkreatur och får i vårt land. Medlemsbl. Sverig. Vet.-Förb. 1963, 15, 29.

Höjer, J. A.: Kropfstudien. Svenska Läk.-Sällsk. Handl. 1931, 57, 1-104.

Johnsson, S.: Endemisk struma-frekvens i Medelpad. Svenska Läk.Tidn. 1965, 62, $2049-2056$.

Kungl. Medicinalstyrelsen: Medicinalväsendet. Samling av författningar och cirkulär mm. no. 11, 1966.

Obel, A.-L., K. Sjöberg \& H. Sandstedt: Om medfödd struma hos kalv i Sverige. Nord. Vet.-Med. 1950, 2, 491-507.

Roche, J. \& S. Lissitzky: Etiology of endemic goitre. In Endemic Goitre. WHO Monograph series no. 44, Genéve 1960, 351-368.

Thorell, C. B.: In vitro erythrocyte uptake and serum protein binding of I'131-labelled L-3,5,3'-triiodothyronine as thyroid function tests in cattle. Acta vet. scand. 1965, 6, Suppl. 4, 1-64.

Wahlberg, J.: Zur Kenntnis der normalen und pathologischen Histophysiologie des menschlichen Schilddrüsenepithels. Arb. path. Inst. Univ. Helsingfors. G. Fischer, Jena 1933, 7, 197-330.

Wang, Y.: In vitro studies of thyroid function with erythrocyte uptake of I $^{131}$-labelled triiodothyronine. Acta endocr. (Kbh.) 1963, 42, Suppl. 76, 1-44.

\section{SLMMARY}

Autopsy studies of the thyroid gland in lactating cattle were combined with chemical tests of thyroid function, i.e. protein-bound iodine (PBI) in serum, and uptake by the erythrocytes in vitro of I ${ }^{131}$-labelled L-triiodothyronine (EU). The study was made on 255 cows from 5 different slaughterhouses in Sweden. To permit a comparison with the chemical results, the thyroids were classified morphologically as normal, slightly changed, and moderately to greatly changed, respectively. 
The term goitre was used to denote those glands whose weight exceeded $54 \mathrm{~g}$ in SRB cows, $51 \mathrm{~g}$ in SLB cows, and $44 \mathrm{~g}$ in SKB cows.

Examination of glands from cows in the Sundsvall region showed $85 \%$ to be the site of histological changes, which were denoted as moderate to marked in $72 \%$ of them. The corresponding figures for the östersund region were 68 and $28 \%$, respectively. In the other sampling regions, the figures ranged from $40-52 \%$ and from $21-$ $28 \%$ respectively.

Totally 12 thyroids were found to be goitrous; 5 of them derived from the Sundsvall region, and 3 from the östersund region. All but 2 of the cows with goitre were chemically euthyroid.

Cows from the Sävsjö, östersund and Halmstad regions had significantly lower EU values than cows from the Uppsala and Sundsvall regions. No corresponding difference was present between the various regions with respect to PBI. Cows with morphologically changed glands had higher PBI values than cows with morphologically normal glands. There was a poor correlation between the nature of the histological change and the results of the chemical analyses.

\section{ZUSAMMENFASSUNG}

\section{Klinisch-chemische und morphologische Studien}

über die Schilddrüsenfunktion laktierender Rinder.

Histo-pathologische Studien der Schilddrüse laktierender Rinder wurden mit 2 klinisch-chemischen Thyreoideafunktionstesten kombiniert, der Bestimmung der Erythrozytenaufnahme in vitro von $\mathrm{J}^{131}$ gemerktem Trijodthyronin (EU) und des proteingebundenen Jodes (PBJ) im Serum. Die Untersuchungen wurden an 255 Rindern von 5 verschiedenen Schlachthäusern in Schweden ausgeführt. Um einen Vergleich mit den klinisch-chemischen Resultaten zu ermöglichen, wurden die Schilddrüsen aus morphologischen Gesichtspunkten in normale, leicht sowie mässig/stark veränderte, eingeteilt. Die Bezeichnung Struma wurde bei den Drüsen, deren Gewicht bei SRBRindern $54 \mathrm{~g}$, bei SLB-Rindern $51 \mathrm{~g}$ und bei SKB-Rindern $44 \mathrm{~g}$ überstieg, angewendet.

Die Untersuchung der Drüsen aus dem Sundsvallgebiet ergab, dass $85 \%$ histo-pathologische Veränderungen aufwiesen, davon $72 \%$ mässig/starke. Entsprechende Ziffern für das östersundsgebiet sind 68 resp. $28 \%$. In den übrigen Probenahmegebieten variieren die Werte zwischen $40-52$, resp. $21-28 \%$.

Totál wurden 12 Strumadrüsen gefunden, davon 5 vom Sundsvallund 3 vom östersundsgebiet. Sämtliche Rinder, ausser 2, bei denen Struma konstatiert wurde, konnten klinisch-chemisch als euthyreote bezeichnet werden.

Rinder vom Sävsjö-, östersund- und Halmstadgebiet wiesen signifikant niedrigere EU-Werte auf, als die vom Uppsala- und Sundsvallgebiet. Entsprechende Unterschiede zwischen den PBJ-Werten liegen bei Rindern von den verschiedenen Probenahmegebieten nicht vor. 
Rinder mit histologisch veränderten Schilddrüsen wiesen höhere PBJWerte auf, als die mit morphologisch normalen Drüsen.

Zwischen den Arten der histo-pathologischen Veränderungen und den klinisch-chemischen Untersuchungsresultaten besteht eine schlechte Korrelation.

\section{SAMMANFATTNING \\ Kliniskt-kemiska och morfologiska studien av sköldkörtelfunktionen hos lakterande nötkreatur.}

Histopatologiska studier av thyreoidea hos lakterande nötkreatur har kombinerats med 2 olika kliniskt-kemiska thyreoideafunktionstester, bestämnig av erytrocytupptaget in vitro av $\mathrm{J}^{131}$-märkt L-trijodthyronin (EU) och protein-bundet jod (PBJ) i serum. Undersökningen har utförts på 255 kor från 5 olika slakterier i Sverige. För att möjliggöra en jämförelse med de kliniskt-kemiska resultaten har sköldkörtlarna ur morfologisk synpunkt indelats i normala, lindrigt samt måttligt/kraftigt förändrade. Beteckningen struma har använts på de körtlar vilkas vikt hos SRB-kor överstigit 54 gram, hos SLB-kor 51 gram och hos SKB-kor 44 gram.

Av de körtlar från Sundsvallområdet som undersöktes var $85 \%$ histologiskt förändrade, varav $72 \%$ av körtlarna bedömdes vara måttligt/kraftigt förändrade. Motsvarande siffror för östersundsområdet var 68 respektive $28 \%$. För övriga provtagningsområden varierade dessa siffror mellan $40-52$ respektive $21-28 \%$.

Antal strumakörtlar uppgick i materialet till 12 stycken, därav 5 från Sundsvall- och 3 från östersundsområdet. Samtliga kor utom 2 hos vilka struma konstaterats voro kliniskt-kemiskt euthyreota.

Kor från Sävsjö, östersund- och Halmstadsområdena uppvisade signifikant lägre EU-värden än kor från Uppsala och Sundsvallstrakten. Ingen motsvarande skillnad mellan PBJ-värden föreligger mellan kor från olika provtagningsområden. Kor med histologiskt förändrade sköldkörtlar uppvisade högre PBJ värden än kor med morfologiskt normala körtlar. Det föreligger dålig korrelation mellan de histopatologiska förändringarnas art och de kliniskt-kemiska undersökningsresultaten. 